\title{
An Analysis of How Building a Collaborative Community of Professional Social Studies Teachers through Targeted Ambient Professional Development Impacts Social Studies Classroom Practices
}

\author{
Karen Thomas-Brown ${ }^{1}$, LaShorage Shaffer ${ }^{1}$, Sharon Werner ${ }^{1}$ \\ ${ }^{1}$ Department of Education, University of Michigan-Dearborn, Dearborn, Michigan \\ Correspondence: Karen Thomas-Brown, University of Michigan-Dearborn College of Education, Health, and Human \\ Services, Department of Education, Fairlane Center South, 19000 Hubbard Drive, Dearborn, Michigan, 48126, USA.
}

Received: August 17, 2016

doi:10.11114/jets.v4i11.1814
Accepted: August 22, $2016 \quad$ Online Published: September 23, 2016

URL: http://dx.doi.org/10.11114/jets.v4i11.1814

\begin{abstract}
This study examined the impact of a yearlong ambient professional development (PD) program-The Wayne Schools Global Geography Project (WSGG-project)-that focused on improving teacher quality through PD and classroom observations for in-service social studies teachers. The project targeted middle and high school social studies teachers and used theory of instruction, theory of teacher change, and constructivist learning as the primary pedagogy pivot. A mixed methods approach was utilized for data collection in the forms of surveys, questionnaires, observations, pre/posttests, and focus groups. Results support the use of intensive, sustained, and content-specific PD to improve teacher content knowledge, pedagogy, and for the development of skills and strategies when teaching social studies. In addition, the formation of a Collaborative Community of Professional Teachers (CCPT) evolved as teachers examined, theorized, and reported on their perceptions of how the project impacted their social studies classroom practices.
\end{abstract}

Keywords: professional development, pedagogy, content knowledge, social studies

\section{Introduction}

\subsection{Introduction and Background}

This article presents the outcomes of the Wayne Schools Global-Geography Project (WSGG-project), a yearlong professional development (PD) project that offered sustained, intensive content knowledge, constructivist inclusive pedagogy, and interactive classroom resources specific to $6^{\text {th }}, 7^{\text {th }}$, and high school social studies. The WSGG-project was school-based and directly related to social studies topics the teachers were expected to teach. This research covers a social studies PD project that is primarily observational as identified by Wayne, et al. (2008). Observational in that it tested whether certain criteria of PD were related to teacher effectiveness as measured by teachers' ability to raise student achievement. The WSGG-project was a partnership between three different departments across two universities, the Wayne Regional Educational Authority, and selected school districts identified as high-needs local educational agencies (high-need LEA). The project focused on improving teacher quality through approximately 109 hours of PD workshops and activities over a twelve-month period. The project focused on social studies content related to state grade level standards for covering Eastern \& Western Hemisphere Studies, Contemporary Global Issues, and an introduction to Era 7-Global Crisis and Achievement 1900-1945. This PD project was an attempt to address some of what Vontz, Franke, Burenheide and Bietau (2007) refer to as gulfs between social studies leaders and teachers that interfere with capacities to respond to priorities and to improve social studies education.

The short-term goal of the WSGG-project was to provide participating teachers with the resources and knowhow needed to better use new knowledge, strategies, and materials for teaching the targeted social studies content areas. Enhancing teachers' knowledge, skills, and classroom practice through sustained interactions and collaborations was therefore crucial to this project (Darling-Hammond, 1997 and 1999; Desimone, 2002, 2009, and 2011; Estrada, 2005). The short-term goal of the project was tied to the desired long-term outcome, which was to ensure that the teachers were able to enhance students' learning and achievement in social studies. Through exposure to strategies, skills, and materials provided in the PD workshops and follow up instructional activities, both short-term and long-term goals were addressed. 
Hence, the fundamental task for the project team was to improve the design and delivery of content-rich materials and strategies to the teachers.

To ensure the achievement of short term and long-term goals, the WSGG-project had four measurable objectives: (1) increase teachers' social studies content knowledge competency; (2) develop material-based strategies to integrate social studies content, thinking and reasoning; (3) foster teachers' adaptation and utilization of Universal Design for Learning (UDL) principles (Binko, 1997; Rappolt-Schlichtmann, Daley \& Rose, 2012; Wiggins, 1998); and (4) measure teachers' and, potentially, students' outcomes. The aforementioned project objectives guided the research question and sub questions this study attempted to answer. Additionally, the project goals gave consideration to Desimone Path-model (2009). This model aligns with the work of Estrada (2005), and Darling-Hammond (1997) and extrapolated that effective PD should increase teachers' knowledge, skills and improve practice. The fundamental desired outcome of any in-service PD effort is to increase student achievement, which may be hinged on programs that incorporate the five core components of the path-model: "(1) content focus, (2) active learning, (3) coherence, (4) duration, and (5) collective participation" (Desimone, 2009).

\subsection{Why is PD a Necessity for In-service Teachers?}

The WSGG-project was grounded in three conceptual positions. The first, theory of instruction (Wayne et al., 2008) focused on teachers' specific content knowledge and pedagogy. In this conceptual position the research assumed that there is value to be derived from extended in-service PD on teachers' short- and long-term classroom practices (Libbee, Mater and Schaftenaar, 1999; Wayne et al., 2008). The second conceptual position posits that intense exposure to targeted social studies content knowledge and pedagogy increases the likelihood that teachers will implement sound instructional practices. In this regard, the focus was on theory of teacher change; that is, participation of teachers in ongoing PD that concentrated on exposure to specific social studies content. Throughout the PD workshops pedagogy and collaboration with the intention of impacting teachers' perceptions of their classroom practices was installed. The third, constructivist learning, offers more long-term value to their students as demonstrated by UDL (Binko, 1997; Rappolt-Schlichtmann, Daley \& Rose, 2012; Wiggins, 1998). Therefore, the challenge of PD lends credence to "teachers' characteristics and experiences - contexts, approaches and the purpose for professional development" (Estrada, 2005, 322). These assumptions underpin the conceptual framework where interactive relationships exist among the core features of PD, teacher knowledge and beliefs, classroom practices, and ultimately student outcomes (Darling-Hammond, 1997 and 1999; Desimone, 2011 and 2009; Desimone et. al., 2002; Estrada, 2005). Hence, when teachers participate in effective PD experiences instructional change should take place.

Professional development efforts are historically rooted in five fundamental educational reform agendas representing district and local concerns (Little, 1989 and 1993). These five reform agendas centers around (1) subject matter teaching; (2) problems of equity and diversity; (3) the nature, extent, and uses of student assessment; (4) the social organization of schooling; and (5) professionalization and professionalism in teaching (Little, 1993). Successful reform relies upon a common pathway of quality instruction in classrooms - and developing student knowledge is contingent upon teachers' enhancing their capacities to engage in quality instructional practices (Darling-Hammond, 1997 and 1999). According to Estrada (2005) these effective classroom practices encapsulate joint productive activities, cognitive complexity, contextualization, and cross-disciplinary understandings.

Howell and Saye (2016) posit that a resolution is needed for existing PD opportunities for teachers. Research has asserted that PDs for social studies teachers should effectively promote teacher learning, socialization, and change, while fostering a culture of shared professional teaching knowledge. Hence, teachers' retention of knowledge is conceptualized as a complex system, rather than a single event (Opfer \& Pedder, 2011), justifying a sustained year-long program.

Traditionally, most school districts offer PD throughout the school year however; sustainability of information acquired can be limited, if not nonexistent. According to Opfer and Pedder (2011) and Desimone (2009) dissecting the true impact of PD lends itself to identifying the complex, interrelated, and reciprocal professional knowledge of teachers'. Research conducted by Desimone (2009) suggests that duration- PDs spread over an extended time period of at least 20 hours is more effective in impacting intellect and pedagogy among teachers. Creating an environment where teachers are able to willingly and positively express their perceptions of their craft with confidence aligns with the importance of PD being hosted in a collaborative setting. Extended PDs have the potential to unveil teachers' perception of the impact of the PD on their content knowledge and pedagogy. In addition, extended PDs increase the likelihood that teachers will conduct sound instructional practice irrespective of the economic, geographic and policy constructs that govern their schools (Grant, 2005; Hong \& Hamot, 2015; National Council for the Social Studies, 2007).

Professional development models using the theory of instruction approach should be contextualized by situating PDs within locations where the content to be covered is valued, needed, and will be used (Desimone, 2009 and 2011; Wayne et al., 2008). Pivoting on the work of Kennedy (1989), this social studies PD focused on high quality, relevant social studies 
content based on the grade level taught by the participating teachers. According to Wayne et al., (2016) "sustained, job-embedded PD focused on the content of the subject that teachers teach is more likely to improve teacher knowledge, classroom instruction, and student achievement". Further contextualization comes from existing PDs in the school districts but "ambient PD, indicates that it pervades the context in which the study takes place" (p. 473), which has significant value provided its context is neither contradictory nor repetitive when compared to other PD offerings in which the teachers simultaneously participated.

\subsection{Effective Professional Development}

According to Wayne et al. (2008), one measure of an ambient PD experience is teacher participation. The desired outcome of effective professional learning that anticipates improving teachers' effectiveness through a community of learners (Libbee, Mater \& Schaftenaar, 1999). Epistemologically, the conceptual framework of this paper is grounded in the notion that teachers essentially transcend the notions of a Professional Learning Community (PLC) (Servage, 2009). Through this project the teachers transitioned into a Collaborative Community of Professional Teachers (CCPT). Teachers shared and produced individual and collective beliefs about knowledge and practice. The teachers became active contentious learners and purveyors of knowledge, in which collaborative efforts engendered group-norms and practices. Furthermore, within this CCPT teachers simultaneously evolved into the professional teacher as: scientists, caring moral agents, advocates for social justice, and learning managers (Servage, 2009).

The concomitant effectiveness of the WSGG-project was embedded in Opfer and Pedder (2011) "process-product conceptualization of causality... effective PD will improve teacher instructional practices, which will result in improved student learning". The project adopted criteria and models developed by Gersmehl (2006 and 2008), Wiggins (1998) and Binko (1997). These writers recommend an in-service workshop strategy that engages teachers in challenging, applicable, and transferable activities as an effective means of tackling teachers' knowledge and skill deficits while building their social studies and real world understandings and socio-spatial intelligence.

\subsection{How Should an Effective Social Studies Classroom Look?}

An aim of this project was to craft and reinforce in participants a comprehensively intricate knowledge structure in social studies to foster instructional authority, an outcome that could only be achieved through long-term training and interaction. "In essence, examining the effects of professional development is analogous to measuring the quality of teachers' learning experiences, the nature of teacher change, and the extent to which such change affects student learning" (Desimone, 2009). Multiple classroom observations are perceived to be the most unbiased form of data collection, whereas, surveys and interviews allow for an examination of what is actually happening during the PD and subsequently in the classroom (Desimone, 2009).

In order to ensure participants sustained and generalized information, practices, and strategies learned through the WSGG-Project, the project team modeled and applied the three principles of UDL (Engagement, Representation, and Action and Expression), which specifically support the knowledge and engagement of teachers (Nelson, 2014; Rappolt-Schlichtmann, Daley \& Rose, 2012; Vontz, Franke, Burenheide \& Bietau, 2007). The principles of UDL provided teachers with the opportunity to learn and practice the following guidelines: (1) options for perception; (2) options for language and symbols; (3) options for comprehension; (4) options for physical action (with access to assistive technology); and (5) options for expressive skills and fluency (linking with common core). Additional UDL guidelines to which the teachers were exposed included (6) options for executive functions; (7) options for recruiting and maintaining interest; (8) options for sustaining efforts and persistence; and (9) options for self-regulation providing tangible exemplars of how they may incorporate these into social studies teaching (Meyer, Rose, \& Gordon, 2013). Incorporating the UDL framework throughout the PD allowed teachers to acquire an understanding of its meaning and skills for effective implementation in their own classrooms.

The impact of social studies PDs may be viewed through the "lens of opportunity" (Pullin \& Haertel, 2008) to provide teachers with collaborative dialogues about planning and implementation of lessons for specific classrooms. According to Howell and Saye (2016) "providing opportunities for teachers to encounter, interpret, and integrate research-based knowledge... and practices" can impact teaching experience on pedagogy as applied to social studies.

\section{Method}

The forgoing outlines the project goals and objectives, this paper reports on the extent to which the project achieved these goals by answering the following research question and sub-questions: How has participating in a yearlong ambient social studies PD impacted knowledge transfer and classroom practices among a group of social studies teachers? Embedded in this broader research question are the following sub-questions:

I. To what extent has knowledge transfer occurred as demonstrated by the teachers' content knowledge competency while teaching social studies in their classrooms? 
II. To what extent did the teachers incorporate the materials and resources provided into their teaching of social studies?

III. How have the teachers adapted and implemented the pedagogy covered during the PD program?

IV. To what extent does the teachers' self-reporting about the impact of the PD program on their classroom practices correspond with actual classroom observations?

To answer the research question and sub-questions, data from a standardized needs assessment survey and teachers' pretest and posttest were analyzed. Classroom observation data were also crucial to the findings of this paper. Additionally, data from a focus group conducted in March 2016 and a post assessment-survey conducted in June 2016 were analyzed and reported in individual and aggregate form.

\subsection{Population Selection and Procedure}

The selection of teachers who participated in this PD project followed guidelines of the funding agency. The State Department of Education targeted schools based on the social and economic status (SES) of the students, predetermining the qualifying school districts. Personnel from Wayne RESA partnered with the project to recruit teachers by creating and distributing a recruitment flyer, fielding inquiries, and ensuring that interested teachers met all the criteria laid out by the State Department of Education. Selection priority was given to $6^{\text {th }}$ and $7^{\text {th }}$ grade social studies teachers, first in the targeted high needs LEAs, followed by teachers in neighboring public schools and then, teachers from independent, private, and charter schools targeted districts.

Once it was determined that the interested teachers met the recruitment criteria, they were asked to complete the standardized needs-assessment survey. This survey was specifically aimed at ascertaining the teachers' social studies content, pedagogy and PD needs. In the end, 41 teachers indicated an interest in program participation. Thirty-one of the 41 teachers completed the required needs-assessment survey, and 35 teachers signed a Memorandum of Understanding (MOU) committing to participate in the project. Sixteen of these teachers taught $6^{\text {th }} \& 7^{\text {th }}$ grades, eight taught $8^{\text {th }} \& 9^{\text {th }}$ grades; and five taught high school social studies. The remaining respondents $(\mathrm{n}=2$ teachers) did not indicate which grades they taught. More than $60 \%$ of the respondents taught at $6^{\text {th, }} 7^{\text {th }}$ and $9^{\text {th }}$ grades.

Thirty-five teachers met the selection criteria and submitted all required documents by July 2015. Based on funding limitations, the project aimed to accommodate 25 teachers, thus 10 of the 35 teachers were waitlisted. Despite their waitlist status, all 35 teachers were invited to attend the summer institute in August 2015. The summer institute comprised of seven full-day workshops, all the teachers attended a minimum of four days. At the end of the summer institute, 30 teachers signed up for at least one of the workshops offered in fall 2015. Between October 2015 and June 2016,28 teachers participated in $88 \%$ of the workshops offered and 22 teachers participated in classroom observations.

Demographically the group of 28 teachers who remained with the project was diverse. They ranged in age from 32 to 60 years; there were four Caucasian males, one African American male, one Arab American female, eight African American females and fourteen Caucasian females. The teachers were from Detroit Public Schools $(n=9)$, Taylor Schools ( $n=6)$, Dearborn Punlic Schools ( $\mathrm{n}=4$ ), and other school districts including Canton, Livonia, Westland and private schools ( $\mathrm{n}=9$ ). All of the teachers had between 5-30 plus years of teaching experience and all, except for five special education co-educators, were social studies or history majors in their undergraduate programs. All of the teachers volunteered to be a part of the project, submitted signed MOUs, photo releases and consent agreements.

\subsection{Data Collection}

Desimone (2009) noted that emphasis should be placed on the "importance of adhering to well-known tenets of research design and instrumentation in evaluating the relative merits of measures of instruction". The instruments used in the data collection process describe the variables measured by this study. To assess the outcome and predictor variables the project relied on four key data sources. Note that each data collection instrument is described in order of chronology of administration, this allows for a holistic view of the project and clear view of the intersections of how each instrument informed the administration and analysis of the others.

The first data source administered in October to November 2014, and it was a standardized needs-assessment survey, which was required by the MDE-ITQ (Title II) grants office. MDE presented a list of recommended items to be included in this instrument and the project team added project-specific items. The data from this survey was used to determine the focus areas for the project. This survey was administered prior to planning the structure of the PD program and was used as a formative assessment tool. This survey consisted of approximately 40 questions, 35 of which were closed-ended. The remaining five open-ended questions asked the teachers about their perceptions on UDL and other pedagogical theories used to design the project. The questions were organized into the following headings: demographics (education, teaching experience); social studies content and pedagogical knowledge; social studies teaching practices, student activities; ideas about teaching and learning social studies; and barriers to implementation. 
The second data source, administered summer 2015 and summer 2016, was the pre and posttest survey that consisted of a combination of 27 questions for the teachers. The questions were a combination of closed-ended; open-ended, and attitude scale questions. According to Silverman (2000), attitude-rating scales is the most widely used research approach within opinion surveys. The Likert scale according to Klooster, Visser, and de Jong (2008) is well accepted because of its simplicity, reliability and its ability to be substituted for perception scales. The pretest surveyed and reported on four variables. The first was the importance and usefulness of geospatial tools, technologies, and representations. The second variable focused on place-based and geographic knowledge related to key world regions and countries. The third variable evaluated access to and use of multiple sources of information to facilitate spatial awareness, thinking and reasoning, and cultural competency. The fourth variable was comfort with teaching geographic materials in the future.

The third data source, and one of the most important for this paper were the classroom observations. The project team designed an observation debriefing form. The classroom observations took place between January and March 2016. Twenty-eight teachers volunteered to be observed, however, 22 were seen due to scheduling and availability. Classes ranged from grades $6^{\text {th }}$ to $10^{\text {th }}$ averaging 32 students. Classroom observations were cross-sectional and evaluated against specific project-based criteria using a scale of 1-5 with 1 representing not evident or minimum level of engagement and 5 representing high level of engagement. The observation criteria were: (1) Evidence that project-based resources were displayed in classrooms and used during social studies teaching; (2) Teachers' lessons and responses to students demonstrated spatial thinking and reasoning skills, historical reasoning, and global perspective; (3) Social studies lessons and classroom discussions demonstrate tangible connections between the resource used and the subject matter being taught; (4) Students' responses demonstrating understanding or use of spatial thinking skills; (5) Evidence of use of higher-level thinking questions and answers; (6) Connection to the state social studies Grade Level Content Expectations (GLCE) and High School Content Expectations (HSCE); (7) Evidence of scaffolding and use of modifications for students with diverse needs/abilities; and (8) Use of targeted formative feedback.

The fourth data source for this paper was the focus group. The focus group was conducted at the end of March 2016, eight months into the program. Ten teachers were randomly selected and organized into groups for participation. The teachers were asked seven questions during the focus group (see Table 5).

The fifth data source used to answer the research questions in this study was an assessment-survey administered in June 2016, which consisted of open-ended questions. Twenty teachers responded to the following questions: (1) Describe 3-5 ways the WSGG-Project has built your capacity to provide effective opportunities for students to learn in your social studies classroom/s; (2) Describe 2-3 examples from your classroom of how the WSGG-Project has allowed you to enhance the learning opportunities of your students, including those with diverse needs? (3) In what ways have you changed your teaching since you began participating in this project? Teachers were encouraged to write freely, to interpret the questions as they saw fit, and were provided additional paper as needed. After the teachers completed their responses individually, the whole group discussed the questions while the researchers took notes.

\subsection{Data Analysis}

Several data analysis methods were employed in this aspect of the project. First, the pre and posttest survey was analyzed in three stages. Quantitative data collected from the survey were analyzed with frequencies and percentage distribution of responses used to identify patterns and trends. This phase was aimed at assessing the importance attached to geospatial tools and geopolitical knowledge. Second, narrative analysis was used to examine responses to the open-ended questions. According to Thomas-Brown and Richards, (2015); Thomas-Brown (2011); Denzin and Lincoln (1994); and Connelly and Clandinin (1990) the educational importance of this line of work brings forth theoretical ideas about the nature of an individual's lived experiences within the context of their educational experiences and classroom practices. The narratives of the teachers provided a useful framework for identifying the extent to which they were able to combine their pedagogy and knowledge gained from this PD to foster more effective classrooms practices. This is tied to our assumption that the more competent their social studies knowledge and pedagogy, the more confident and comfortable they should be with teaching relevant topics and materials. The trends and patterns that emerged from the quantitative data analysis were then cross-referenced with the narratives to validate and support each finding.

The focus group data consisted of a modified process in which the participants first completed a written survey containing the target questions. Surveys were then handed to the facilitator and the questions addressed in a typical focus group discussion. Confidentiality of individual responses was assured and permission obtained from all those present to voice record the interaction. Data from written surveys and audio segments were analyzed using Excel $^{\odot}$ and $\mathrm{NVivo}^{\odot}$. Topics discussed were categorized and reported by number of responses. Word frequencies were identified using NVivo $9^{\odot}$. Data analysis for the assessment-survey utilized both quantitative and qualitative analytic approaches through $\operatorname{Excel}^{\odot}$ and NVivo $9^{\oplus}$, respectively. 


\section{Findings}

In this section the number of teachers included in the analysis will be a reflection of the numbers who completed each data collection instrument; thus, not an aggregate of the entire group. Each data source is reported on separately since they each served a different purpose in answering the research question. In this section we report on data collection tools in chronology of administration because this presents a clear picture of the project from the planning to implementation phase.

\subsection{Results from Standardized Needs Assessment Survey}

The scores from the standardized needs assessment survey indicated the following: first, the greatest areas of PD needs $(n=28$ of the 31 teachers) were incorporating real-world applications into lessons; learning how to integrate other curricular topics into lessons; learning how to align curriculum, instruction, and assessment with state education standards; and challenging students to accept and share responsibility for their own learning. This data supports and justified the project's efforts to integrate UDL and other strategies; and demonstrates the need to incorporate application-oriented sessions into the PD workshops.

The second finding showed that more than $70 \%$ ( $n=23$ of the 31 teachers) indicated that they were more amicable to PDs that were formatted as workshops, conferences, and institutes. Despite the fact that the literature suggests that the format/structure of PDs was secondary to the substance (Desimone, 2015), this project needed to accommodate the teachers' needs. Hence, this project adapted several structures, which included a summer institute. There were two to four workshops each month between October 2015 and June 2016. The WSGG-project also had classroom observations, group planning sessions, and individual consultations.

The third finding focused on social studies disciplinary knowledge and skills (see Table 1). Twenty-eight of the 31 teachers indicated, by using a 3 or above on the 0-5 Likert scale, that they needed assistance in subject matter content and skills related to the geographic themes of the world in spatial terms, places and regions, human systems, environment, and society. Middle school teachers indicated a higher need for geography content (rating their needs a 4 or 5 on the 5-point Likert scale). High school teachers indicated the need for more content knowledge in the global perspective through a historical and geographic lens. Approximately 50\% of the middle school teachers indicated that they needed this content knowledge similar to the high school teachers. Twenty-four teachers indicated a high need in content areas related to analysis of world history eras 4-8 from a global perspective, and regional and interregional perspectives. Finally, when asked to indicate the topics they thought should be covered in PDs, all of the middle school teachers and two of the high school teachers selected topics related to Eastern and Western hemisphere studies, including WWII, Asian history, Continental Africa, population growth and integrating global historical events into geography. This data guided the project's choice of Eastern and Western Hemisphere Studies in combination with Era 7 and Contemporary Global Issues.

Table 1. PD needs regarding subject matter content and skills

\begin{tabular}{|c|c|c|c|c|}
\hline \multirow{2}{*}{$\begin{array}{l}\text { Criteria } \\
\text { Need: Low } 0-5 \text { High average scores of } 17 \mathrm{~K}-8 \text { \& K-12 respondents }\end{array}$} & \multirow{2}{*}{$\begin{array}{l}\text { Mean } \\
\text { Ratings }\end{array}$} & \multicolumn{3}{|c|}{ Priority-Frequency } \\
\hline & & Yes (1) & No $(0)$ & None \\
\hline 1. The world in spatial terms & 3.4 & 12 & 3 & 2 \\
\hline 2. Places and regions & 3.4 & 13 & 2 & 2 \\
\hline 3. Human systems & 3.5 & 14 & 1 & 2 \\
\hline 4. Environment and society & 3.4 & 13 & 2 & 2 \\
\hline \multicolumn{5}{|l|}{ Need: Low 0-5 High average scores of $139-12 \&$ K-12 respondents } \\
\hline 5. Historical and geographical knowledge and perspective & 2.3 & 7 & 3 & 3 \\
\hline Historical and geographical analysis and interpretation & 2.6 & 7 & 3 & 3 \\
\hline Global analysis of world history eras 4-8 from global perspective & 3.5 & 9 & 2 & 2 \\
\hline Global analysis of world history eras 4-8 from interregional perspective & 3.2 & 8 & 2 & 3 \\
\hline 9. Global analysis of world history eras $4-8$ from regional perspective & 3.0 & 7 & 3 & 3 \\
\hline 10. Historical and geographical knowledge and perspective & 2.3 & 7 & 3 & 3 \\
\hline 11. Historical and geographical analysis and interpretation & 2.6 & 7 & 3 & 3 \\
\hline 12. Thematic analysis of United States eras 6-9 & 2.8 & 8 & 3 & 2 \\
\hline 13. Citizenship in action & 3.4 & 8 & 2 & 3 \\
\hline 14. International economy & 3.3 & 8 & 2 & 3 \\
\hline
\end{tabular}

*Please rate each of the following social studies subject matter areas based on your personal professional development content and skills needs. Check one box for each area using the rating scale where $1=$ low need, $5=$ high need and $0=$ need has already been met. Also indicate whether the item is a high priority for you (yes or no).

The fourth finding indicated that approximately $70 \%$ of the respondents indicated that improving their comfort levels with teaching social studies topics to diverse learners was a high priority need. Analysis of the middle school *Assessment Program (MAP*) scores showed that for every Dearborn Pubic School or Taylor Schools randomly selected, more than $50 \%$ of the students were not proficient in social studies; the same was true for all of the high schools' data analyzed. 


\subsection{Pre and Posttest Survey: Anticipated and Actual Impact of This PD on Classroom Practices}

The pretest survey was administered during Summer 2015 ( $\mathrm{n}=38$ teachers) and the posttest survey in June 2016 ( $\mathrm{n}=25$ teachers). This data collection tool measured the teachers' initial attitudes toward teaching geography and expectations for the PD. Table 2 documents the scaled ratings of the teachers' comfort levels with teaching geography-based social studies topics. This table suggests that at the beginning of the PD program, several of the teachers were new to global geography topics, while others felt that they need more knowledge; in concert, these two factors accounted for the overall lower mean comfort levels reported by the teachers. While there were no statistical significant differences in the post scores/means, this does represent an incrementally positive change in the teachers overall comfort levels with teaching geography-based social studies topics. By virtue of the fact that comfort levels increased, this finding asserts that the teachers began to exercise instructional authority and decision-making. Table 3 used an itemized frequency to deconstruct this increase in the teachers' exercised instructional authority in social studies, thereby supporting this finding.

Table 2. Pre and post response to comfort levels survey-item

\begin{tabular}{llcc}
\hline & \multicolumn{1}{c}{ Item } & Mean ratings \\
\cline { 3 - 4 } & & Pre & Post \\
\hline 1. & How comfortable are you with teaching global geography topics? & 3.77 & 4.35 \\
2. & $\begin{array}{l}\text { To what extent do you think your knowledge and experiences will influence how you make } \\
\text { geographic learning meaningful to your students' lives? }\end{array}$ & 4.27 \\
& & 5 \\
3. & $\begin{array}{l}\text { To what extent do you think you will incorporate the materials, content and strategies provided } \\
\text { into your teaching of social studies? }\end{array}$ & 2.85 \\
4. $\quad \begin{array}{l}\text { With 1 as the lowest, rate the impact you anticipate these materials, content, and strategies will } \\
\text { have on your students' learning of global geography? }\end{array}$ & 4.35 & 4.12 \\
\end{tabular}

*Scales: Items $1,1=$ Not at all comfortable to $5=$ Very comfortable; Items 2 and 3,1 = Not at all to $5=$ Very much; Item $4,1=$ Not at all to $5=$ Highest.

The last column in Table 3 shows the frequencies of the teachers' responses in the posttest survey. In the pretest column, a large number of the teachers did not respond to several of the variables, for those who did, the itemized responses indicated that the teachers had high expectations for how participating in the PD would impact their overall social studies classroom practices. The posttest column in Table 3 demonstrates that the teachers experienced growth in all the itemized components of the PD program. Significant is the fact that social studies content knowledge as applied to classroom practices showed the largest incremental increase. Materials, resources use, and pedagogy, showed significant changes based on the frequency of the teachers' responses to the variable statements. Posttest numbers report that they expect the influence on students to be positive and that they intended to use the materials. The same is true for the frequency of teachers' responses to general expectations variable statements in the table. Finally, Table 3 shows the number of non-responses to the variable statements reduced by 10 .

Table 3. Teachers' pre and post responses to impact of PD on teaching

\begin{tabular}{|c|c|c|}
\hline \multirow[t]{2}{*}{ Transfer of learning variables } & \multicolumn{2}{|c|}{ Frequency } \\
\hline & Pre & Post \\
\hline \multicolumn{3}{|l|}{ General expectations variables } \\
\hline 1. The overall effect on students will be (were) positive & 10 & 23 \\
\hline 2. Overall increases in my knowledge and resources will be (have been) transferred to my classroom & 3 & 11 \\
\hline 3. I hope the PD will (has) address (addressed) my social studies content needs & 2 & 21 \\
\hline \multicolumn{3}{|l|}{ Content knowledge variables } \\
\hline 4. I intend to (have tried to) teach content knowledge to be (have been) covered in PD & 9 & 25 \\
\hline 5. I will incorporate (have incorporated) historical content, reasoning and inquiry & 1 & 23 \\
\hline 6. I will incorporate (have incorporated) maps with virtual tours & 3 & 24 \\
\hline 7. I will (have) teach (taught) geography with a team approach & 2 & 15 \\
\hline 8. I will (have) make connections to the 5 themes of geography & 1 & 23 \\
\hline 9. I will (have) use materials for vocabulary with visual tours & 2 & 19 \\
\hline 10. Incorporated the $\mathrm{C} 3$ framework and state social studies content standards & 1 & 25 \\
\hline \multicolumn{3}{|l|}{ Materials and resources variables } \\
\hline 11. I will try to (have) incorporate all materials and resources provided & 4 & 19 \\
\hline 12. I will try to (have) incorporate some of the materials and resources provided & 4 & 6 \\
\hline 13. I will (have) use (used) CDs, videos and interactive tools provided & 3 & 22 \\
\hline \multicolumn{3}{|l|}{ Pedagogy variables } \\
\hline 14. I have had difficulties teaching students with diverse learning needs (I can better accommodate) & 1 & 12 \\
\hline 15. I will incorporate (have incorporated) student inquiry into social studies teaching & 2 & 16 \\
\hline 16. I will incorporate (have incorporated) diverse methods to make learning easier for students & 1 & 22 \\
\hline 17. I will (have) modify (modified) my approach while maintaining content integrity & 1 & 9 \\
\hline Aggregate of the number of times any of the above items remained unanswered by 1 or more teachers & 14 & 4 \\
\hline
\end{tabular}

3.3 Results from Classroom Observations

Classroom observations of 22 teachers took place between January and May 2016. The observed teachers excelled at connecting their lessons to the GLCE/HSCE. Lesson objectives were usually clearly stated either identified from 
statements by the teacher, written on the board with lesson objectives or targets, or daily lesson objectives in notebooks. In these cases, observations showed that it was easy for students to refer to their objectives and measure their own learning. Observations correspond with the representation in Table 4 wherein teachers averaged more than 4 for making connections to the content matter. Despite this, the table shows that the mean score was 2.8 for historical reasoning and global perspective and students' demonstration of understanding; meaning that despite the growth in the teachers' content knowledge, more work still needs to be done to transfer into student competency.

The observed teachers also succeeded in using resources. During the classroom observation debriefing, many of the teachers expressed excitement about the new resources and their ability to immediately use the materials in their classrooms. One example came from a classroom in which the teacher was observed using a PowerPoint presentation from one of the Project workshops to teach students about the equator and how location relative to the equator affects climate. Another example came from a classroom in which the teacher structured her lesson about migration across the Bering land bridge using the Nystrom Atlas of World History that was provided by the Project. In this instance, the teacher used the atlas for information, images, maps, and to teach her students how to use the features of the text.

Table 4. Classroom observation mean ratings $(n=22)$

\begin{tabular}{|c|c|}
\hline Dimension & Mean ratings \\
\hline 1. Resource connection ${ }^{1}$ & 4.4 \\
\hline 2. Resource level of engagement ${ }^{1}$ & 3.2 \\
\hline 3. Responses using spatial skills/historical reasoning/global perspective & 2.8 \\
\hline 4. Connection of resource to subject matter being taught & 4.4 \\
\hline 5. Students' responses demonstrating understanding or use of spatial thinking skills & 2.8 \\
\hline 6. Evidence of use of higher level thinking questions and answers & 2.8 \\
\hline 7. Connection to GLCEs/HSCE & 4.6 \\
\hline 8. Use of scaffolding & 3.2 \\
\hline 9. Evidence of scaffolding for students with diverse needs/abilities & 2.4 \\
\hline 10. Use of targeted formative feedback & 2.4 \\
\hline 11. Use of modifications & 1.9 \\
\hline 12. Attempt to meet the needs diverse learners (low SES, ethnicity, race, gender, disabilities) & 2.2 \\
\hline
\end{tabular}

*Scale: $1=$ not evident or minimum level of engagement to $5=$ evident or high level of engagement

${ }^{1}$ A total of 25 resources were used by the 22 teachers observed.

Notwithstanding the teachers' impressive grasp of the content knowledge covered and use of related resources in their teaching, Table 4 indicates that many needed to improve their classroom practices by modifying lessons to fit the educational needs of all of their students. Nearly all of the observed teachers presented their lessons to their full classes and provided limited modifications of materials and assessments. In addition, classroom observations revealed that 13 teachers used group work as a modification to their lessons. Further, classroom observations identified that the teachers needed more practice in engaging students in higher order thinking, as noted with a mean score of 2.8 for item number six (see Table 4).

Pivoting on the foregoing, in a majority of the classrooms, questioning was used as primary pedagogy. While the choice of questioning as a teaching strategy carries a plethora of advantages, classroom observations showed that the teachers used mainly low-level questions requiring students to identify and recall information rather than analyze, synthesize, evaluate, or judge the relative merits of the information presented. Also, the assignments that students completed in several of the observed classes mainly asked students to retrieve information from text or notes without mental processing. Not all the teachers fell short in terms of strategies used in their classrooms; one notable exception occurred in a lesson about thematic maps. In this instance the students were asked to interpret John Snow's map of cholera cases in 19th Century London and try to determine the cause of the cholera outbreak. The sixth grade students were observed being very interested and engaged in the activity, while using higher order thinking to solve the mystery.

The broad findings from classroom observations have demonstrated growth in teachers' social studies content knowledge and use of appropriate resources. However, low average scores on several of the classroom observation criteria related to pedagogy (e.g. application of UDL principles score of 1.9 in Table 4), suggests that there are some pedagogical disconnects which continue a need for attention. Table 4 demonstrates the level of engagement and the use of scaffolding and suggests that in the area of pedagogy, the project has achieved some success. Overall the classroom observations and resultant data presented in Table 4 denote that there were some discrepancies between what was observed in the classrooms and the teachers' self-reporting on the other data collection instruments.

\subsection{Results from Focus Group}

Two focus groups with the teachers were conducted on March 10, 2016 and included a random selection of 10 teachers who attended that workshop. The responses from each group were highly similar and, therefore, reported in aggregate. 
Data from the hard copy surveys represent the core of the results reported, augmented by verbal comments made during the discussion (see Table 5). This finding indicated that eight months after starting the PD program the teachers remained enthusiastic about both the knowledge and pedagogical skills they gained, as well as the impact they reported that it was having on their classroom practices. All of the teachers reported using the resources provided and all described the benefits of networking and collaborating with teachers from other schools.

During the focus group the teachers delineated the components of their practice on which they felt this yearlong PD had the most impact. The outcomes of this breakdown are: (1) content knowledge-geography, (2) strategies, (3) technology, and (4) the students. Additionally, the teachers' discussions pulled out the theme 'geography' which included descriptions of how they think they are integrating the subject and program resources into their instruction and showed increased confidence and positive attitudes. Some of the significant terms that emerged include 'fun,' 'confident,' 'relevance,' 'my decisions,' and 'technology'. The teachers' perceptions of the impact of the Project on their classroom practices was that of change due to their increased confidence in presenting social studies knowledge using more innovative pedagogy to their students.

Table 5. Summary of responses by focus group question $(n=10)$

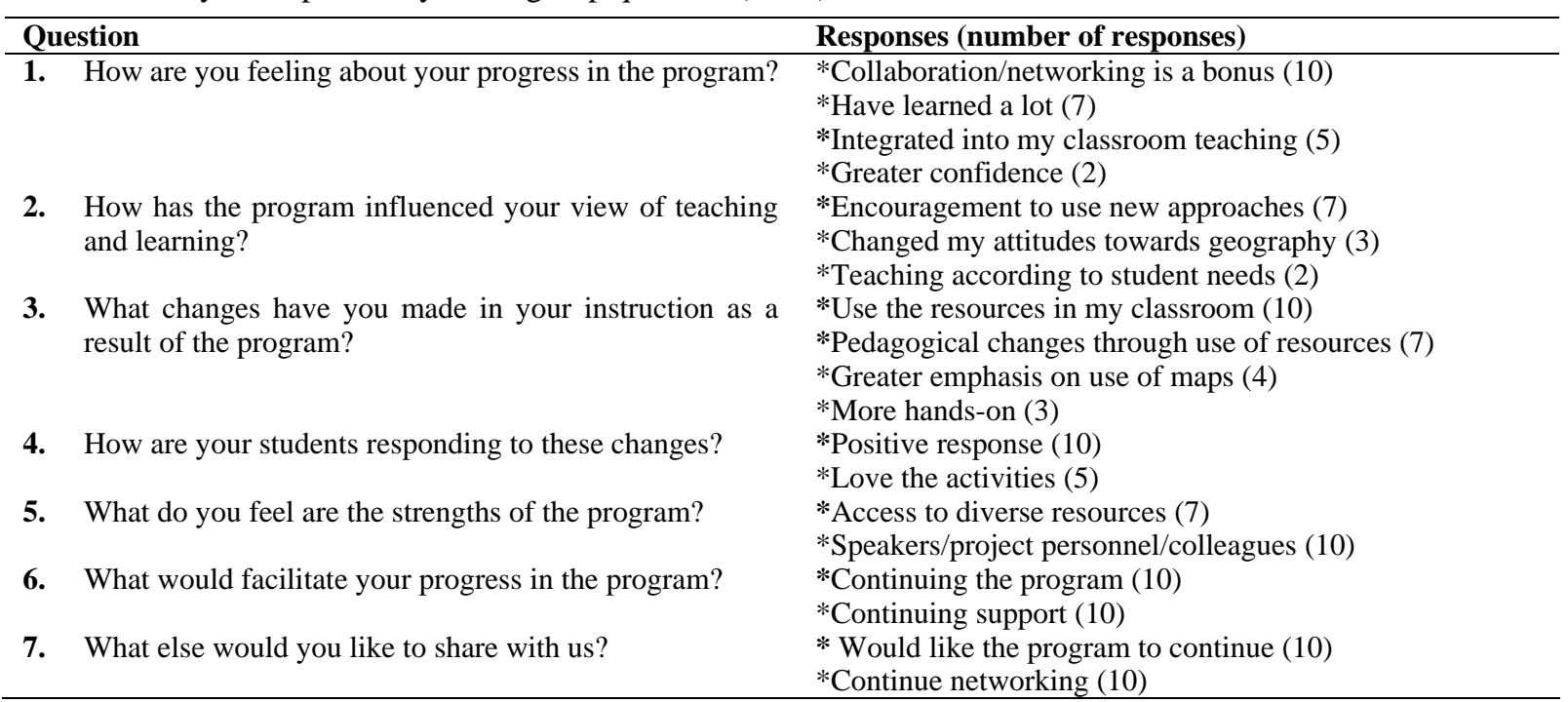

The teachers' articulations about the instructional strategies indicated that those in the focus group felt that they grew in their mastery and implementation of the strategies covered in this PD program; however, this is in contrast to some of the findings from the classroom observations.

\subsection{Results from the Assessment-survey}

Twenty teachers responded to an assessment survey in June 2016. The survey had three open-ended questions regarding the Project's overall impact on their classroom practice. The results are presented in Tables 6, 7 and 8. In Table 6, the teachers responded to question 1: Describe 3 to 5 ways the WSGG Project has built your capacity to provide effective opportunities for students to learn in your social studies classroom. The table demonstrates that seven discreet themes emerged from the teachers' responses. The teachers described the variety of instructional strategies, resources, and technology they received during the program, in addition to other benefits. As one teacher reported, "The WSGG-Project has improved my ability to use formative assessments, incorporate technology, differentiate, use a variety of materials, and use a broad range of content knowledge to make connections that were previously unknown to myself [sic] and my students". (MM) 
Table 6. Teachers' responses and comments to question \# 1

1. Instructional strategies: (1) The project has provided multiple ways of teaching and reaching students. (2) The MGA was amazing! I love the material shared. (3) Ways to share with students. (4) The project provided and taught me new and creative ways to teach history/geography. (5) I have used many activities that were given to us such as climate regions, rain shadow effect, etc. (6) Lessons presented were "real" lessons, just use them in my class. (7) Many different strategies. (8) The modules and lesson overviews has helped me to introduce to students the important aspects of the topics. (9) GP and JP have brought wonderful strategies for us to bring to the classroom. (Warm-ups, Google Classroom, Formative Assessments). (10) I have been given so many wonderful and new ways to make social studies more engaging. (11) The ability to differentiate instruction in my class has really evolved from my learning new methods. (12) Differentiate with "Do Now" activities.

2. Assessment: (1) GIS Tools and materials have helped with formative assessment. (2) Formative assessment information is something I need to do more-- so this will help. (3) I've been able to create better assessment tools. (4) Many new ideas for assessments and assignments. (5) Techniques/Apps formative assessment and new resources.

3. Improved knowledge base: (1) My knowledge has increased! I have learned so much. (2) These presentations have given me a great depth of knowledge that makes me a more effective teacher when using these resources they gave to us. (3) Reading that geography affects a variety of aspects within areas. (4) The content information has helped me be more confident in my own knowledge.

4. Internet resources: (1) I love Google Classroom but can't use it because DPS does not know that it is free!! (2) Google slides.... provides more features than regular PowerPoint. Google-slides has allowed me to incorporate timers within the slide while simultaneously linking videos. (3) The introduction of Websites is an added skill and knowledge enhancer. (4) The website Our Spatial Brains has opened a wealth of resources to explain the world and worldly topics in a more concrete way. (5) Provided access to My Spatial Brains maps \& clickable maps. (6) Strategies such as Kahoot have engaged students to participate in formative assessments.

5. Geography resources: (1) The resources and information (even for myself) shared with me (knowledge base) has made it easier to communicate knowledge learned to my students. (2) Teaching of Geography using World Maps and use of the atlas. (3) WSGG-provided great materials (visuals especially) to display in my classroom. (maps-charts, etc.). (4) The students use the geo-histograms to label what we are covering in class, which is a different approach to the standard timeline. (5) I have used the layered maps to explain trade routes, the spread of humans out of Africa, and the silk road. (6) The layered maps were used to show important events that happened in a certain time. (7) The materials (World History Atlas), Prezi spatial Browns, State Geographic Alliances. (8) Sharing resources with us. (9) The resources shared or given are so helpful.

6. Collegial collaboration: (1) The interaction among peers is inspirational and stimulating. (2) Becoming socially aware. (3) Networking with other Wayne County Social Studies teachers.

7. Motivation: (1) The knowledge of the facilitators has been a wonderful motivator.

Table 7. Teachers' responses and comments to question \#2

1. Internet resources: (1) Google Slide Warm-up activities. (2) World history atlas and student resources. (3) Geo-Histogram with mapping activities. (4) Websites have helped with presentations.

2. Instructional strategies: (1) Practice "see it" and "do it" theory when working with geography. (2) Many innovative and new ideas that I have tried have increased student achievement. (3) Grouping activities from Summer Sessions. (4) Review game inclusive student collaboration. (5) Realized all map information is not processes the same. --Change approach. (6) Shared atlas/mystery picture activity. (7) I am excited to try the new tools from this workshop upon returning to school next week.

3. Materials: (1) The colorful maps, visual resources, and bounds of materials for teaching and student learning have been an added resource. (2) The 2nd best lesson taught because of WSGG materials was that of "mankind movement and development." This lesson coincided with one new History/Geography textbook and I was able to use the "Histogram" chart to record, review, + understand ancient history. (3) Maps, electronic, and paper have been a wonderful tool especially for visual learners. (4) I have used the "History of the world in two hours" video as a review (small segments). (5) I have used a few documents as a teaching tool such as Hammurabi's Code. Hittite Laws etc. (6) Maps were used to demonstrate important events in the world. (7) The maps (worksheets) provided by Geography Alliance presenters-- the students worked on and have in their Social Studies notebooks. (8) The GeoHistogram which I have posted in my classroom + students can refer to, or use their own copies. The five Themes Posters that we refer to almost daily. (9) Map skills--Visual Vocabulary (Visual leaners). (10) Scavenger hunts using World History Atlas. (11) The WSGG Project has enhanced the learning opportunities through access to materials such as Nystrom World Atlas, GeoHistogram, and My spatial Thinking website... have allowed me to develop more engaging, more diverse learning opportunities that benefit a wider array of learners.

4. Differentiation of instruction: (1) Having speakers that name experience with special needs population was most beneficial. (2) Scaffolding. (3) Differentiating lessons. (4) My students need much review and re-teaching. (5) One of the best lessons was that of immigration and migration patterns... As a result of the material provided, I was able to truly "scaffold" the lesson by: 1. Providing a migration chart, 2. Providing a world map. 3. Creating formative questions for the lessons regarding "world cultures" +"Geography". (6) PowerPoint presentations were taught that can be taught to students so can present information in a different way.

5. Student populations and needs: (1) My students need much review and re-teaching. This WSGG Project has allowed the very timid students the opportunity to respond because of the resources. (2) Diversity. (3) I have been able to use these learning opportunities in other subjects with students with various needs. Math and Science i.e., directions left right, shapes, areas. (4) Students are able to build on lessons old and new and make connections. (5) This WSGG Project has allowed the very timid students the opportunity to respond because of the resources. (6) Using more visual materials such as the clickable maps and the Historical atlas materials-they are engaging and reach all learners. (7) The Histogram helped struggling readers SEE a timeline without a lot of intense reading. (8) Games like "I have, who has" enhances the learning opportunities of my students. (9) 'Map" activities are useful for my S.S. because they didn't have any experience in geography, especially not familiar with the western hemisphere.

6. Collegial collaboration: (1) Sharing ex. With teachers from different districts 
Table 7 summarizes the emergent themes and teachers' comments to question 2. This question asked the teachers to: Describe 3 to 5 examples of how the WSGG-Project has allowed you to enhance the learning opportunities of your students, including those with diverse needs. The teachers described six distinct themes that have allowed them to enhance learning opportunities for their students. These themes correspond with the Project aims and objectives outlined earlier, as well as the criteria used to evaluate the classroom observations (see Table 4). As presented in Table 7 the teachers were able to discuss in detail all the resources and strategies they believe have impacted their students' performance in social studies; this finding confirms the outcomes reported on in Table 4 as it pertains to Items 2 and 5.

Table 8 summarizes the emergent themes and teachers' comments in response to question 3 . This question asked the teachers: In what ways have you changed your treatment since you began participating in this project? Among the teachers' responses five themes emerged, all of which correspond with the Projects' goals and the previous findings in this paper. The five themes covered the benefits of the content knowledge, instructional strategies, use of materials and collaboration. This is shown by the statement of one teacher:

This project has been invaluable! The education that I have had the pleasure of meeting are wonderful mounds of intellect on various topics, themes, and classroom. Dr. B drew me in day one with her accent and her wealth of knowledge of the world geographically from the water I drink to the shoes I wear on my feet! My students and family both have benefitted from the knowledge I have obtained. I am truly going to HATE when this project ends. The resources/information/knowledge has been immeasurable. (Anonymous)

Table 8. Teachers' responses and comments to question \#3

1. Instructional strategies: (1) Although I have not had the opportunity to use as a classroom teacher, I have used many during individual teaching, reading, speaking, and sharing information. (2) I have incorporated more cooperative learning for students. (3) I have incorporated more media in the classroom. (4) I have changed by incorporating hands on with the maps. A log of usage of time line maps. Geo-histogram. Resources. (5) Many innovative and new ideas that I have tried have increased student achievement. (6) I have become more flexible with technology tools with caution because my students are really engaged when using technology, however I have to make sure they are focused. (7) Questions should draw students into the learning process as well as checking on acquisition of knowledge. (8) Use effective questioning. (9) I am trying to make learning more student based. I can see that student confidence is higher and they do help one another find answers. (10) I feel like I am more willing to try different things in my classroom. I find myself looking for ways to be more engaging in my classes and creative. (11) Using video can also drive instruction. Students are usually interested in videos. (12) Using apps that were shared with us on different instructional websites. (12) I spend more time on pre-teaching. (13) I have improved my pedagogical skills. For example, teaching strategies, engagement strategies, and assessment strategies have all been enhanced through the WSGG Project.

2. Formative assessment: (1) I can provide more creative formative assessments. (2) My final assessments are more relative. (3) Using Formative activities rather than summative tests, exit tickets to know students understand.

3. Materials/Websites (1) Since I have started participating in this project, I have become a greater learner!! There is an infinite amount of resources that are available to assist within the classroom. (2) I need to do more hands on. (3) Supporting teachers with knowledge/resources they just were not using. (4) I have become more flexible with technology tools with caution because my students are really engaged when using technology, however I have to make sure they are focused. (4) I use more maps in History classes. (5) I have been able to move outside the curriculum to supplement student learning.

4. Greater content knowledge: (1) My knowledge has GROWN-I love sharing what I have learned with the kids.

5. Support network (2) The network of support has been amazing. (2) I am more confident...more secure when teaching the required subject(s). (3) Because I save my lessons and materials, my social studies colleagues come to me for Ideas/questions, etc. (4) Being with other teachers who teach the same subject and can share ideas, materials and resources have also had a huge impact on what I can truly bring to my students. (5) My connection to colleagues and ideas that have been shared through this project have benefitted my teaching and provided access to a professional learning community that will benefit my instruction long after the project has ended.

\section{Discussion and Recommendations}

Examining the outcomes of the WSGG- project revealed four major findings and implications for extended PD in social studies. First, in-service social studies PD must be steeped in a solid theoretical framework that has practical applications for participants if teachers are going to perceive it as impactful. Second, teacher participants should feel as if they are being treated well and that the PD program is responsive to their needs. Third, teacher participants much have buy-in and be prepared to apply the content, skills and pedagogy being taught and reinforced in the extended PDs. By extension this buy-in needs to be associated with achievable goals upon which the teachers can reflect. Fourth, the teacher participants should be able to establish connections between the extended PD program and the various components of their classroom practice on a reflective level that will allow for honest self-assessment. Essentially, PD providers rooted in higher educational institutions must dispel with the ivory-tower prescriptive approach and be willing to meet teachers at the point of their needs, hence continuous reflection should inform PD program structure and implementation.

This research was rooted in the assumption that effective PD should improve teachers' instructional practices, which, by extension, should result in improved student outcomes. Both the literature and the results of this study have shown that 
teachers who have strong academic background, good content knowledge, and pedagogy in the area they teach tend to: (1) exercise instructional authority, (2) practice ambitious teaching, (3) exercise good instructional decision-making, (4) often choose a variety of instructional sources for instructional purposes, (5) expose students to a plethora of viewpoints and (6) have the skills to arouse students interests and critical thinking skills (Grant, 2007; Hong \& Hamot, 2015; Salinas, 2006).

The varied data sources as well as the teachers' reflections reveal that their overall experience with this project positively impacted their content knowledge, pedagogy, resource use and application. Throughout the discussions with the teachers as well as the results of the various data collections tools and methods of analysis, it has been stated unequivocally that the use of resources provided for the teachers by this project was a significant theme. Data showed some discrepancies in the display and use of resources in the classroom observations when compared to the teachers' self-reporting. This opens the door for further discussions as the research results raise questions about the extent to which the resources were only present during the lessons or whether they were actually used on a continuous basis to enhance the teaching and learning process. Additionally, how does the display and use of resources in concert with the pedagogy covered in the project account for the low overall instances of scaffolding? It is the prerogative of the research team to reconcile the gaps between the classroom observation scores and many of the reflective sentiments repeated about the resources by several of the teachers.

Also noteworthy are the discrepancies in the outcomes of classroom observations and the teachers' self-reporting on how the PD actually impacts their classroom practices (e.g. strategy. The impact on strategy, while echoed by the special education co-teachers in the group, was also repeated by some of the veteran general education social studies teachers. Many of these teachers mentioned implementing the strategies in such a way that allowed them to transcend their previous patterns of teaching social studies. Data also indicates that the teachers were unable to separate any one portion of the PD to identify as more valuable or impactful than the rest. What the teachers were able to recognize was the emphasis the Project placed on the targeted content knowledge, pedagogy, and resources use in social studies classrooms.

\section{Limitations}

The results of this study support the need for intensive, sustained, content specific professional development. Nonetheless, limitations should be noted. First, observations of teachers were limited to one due to funding limitations and schedules. Thus, data only presents one point in classroom practices and use of resources. Although, teachers were provided feedback, a second observation was not conducted to show change in practice. Another limitation would be the reliance on teacher self-reports of content knowledge, pedagogy, and use of materials, as opposed to an assessment or multiple observations to capture this data. Multiple data sources could allow for triangulation of the data for validity. The overall outcome of any professional development is to impact student achievement. However, a limitation of this study was not being able to capture this information due to the focus and requirements of the project.

\section{Conclusion}

This article presented a PD project that was intensive, sustained, and content specific, with explicit focus on social studies. The expected outcome was to impact teacher quality in the areas of content knowledge, pedagogy, instructional practice, and student learning. Project participants were provided with resources to enhance and extend their current instructional practices, hands-on instruction to increase the utilization of provided resources, and pedagogical methods and strategies to support student engagement and acquisition of content. Findings indicated that teachers felt more confident and competent in teaching social studies content, utilized provided resources to enhance and extend instruction, and developed a sense of community amongst each other from which a Collaborative Community of Professional Teachers (CCPT) evolved. These outcomes, adding overall to the literature on effective models of PD, support the need for ongoing research in the area of intensive, sustained, and content-specific PD.

Educational reforms and goals require new and continuous learning on the part of teachers for which they will need support and guidance (Ball \& Cohen, 1999; Putnam \& Borko, 1997; Wilson \& Berne, 1999). Professional development is a key approach used to provide in-service teachers with content to enhance knowledge, strategies to support pedagogy, and supplemental resources. However, measuring the impact of PD must encompass multiple layers of data collection including PD content focus, duration, coherence, active learning, collective participation, coaching, mentoring, teacher growth in knowledge and skills, pedagogy, instructional approach, attitudes and beliefs, student engagement, learning, and achievement. Although teacher self-reporting is a viable source of data, multiple opportunities for observational data would strengthen and corroborate self-reported data and validate the overall impact of PD. In addition, using strategies within the UDL framework is another area for continued PD support and research. The ability to capture all of these components across PD requires extensive resources and time. Further research should extend to data collection on teacher content knowledge, effectiveness, UDL, coaching, and student outcomes. Findings 
from continued professional development research will guide and impact policy, practice, and ultimately, student learning, performance and outcomes.

\section{Acknowledgements}

We would like to thank the teachers who participating in this yearlong PD. We would also like to thank MGA for the many trainers who presented valuable sessions to the teachers based on their needs. The research reported here was supported by the M Department of Education, through Title II Part A(3) Improving Teacher Quality Grants (\#150290-031).

\section{References}

Anderson, J. R., Greeno, J. G., Reder, L. M., \& Simon, H. A. (2000). Perspectives on learning, thinking and activity. Educational Researcher, 29(4), 11-13. http://dx.doi.org/10.3102/0013189X029004011

Ball, D. L., \& Cohen, D. K. (1999). Developing practice, developing practitioners: Toward a practice-based theory of professional education. In L. Darling-Hammond and G. Sykes (Eds.), Teaching as the learning profession (pp. 3-31). San Francisco, C A: Jossey-Bass.

Bednarz, S. W., \& Bednarz, R. S. (1995). Preservice geography education. Journal of Geography, 94(5), 482-486. http://dx.doi.org/10.1080/00221349508979351

Binko, J. (1989). Spreading the Word about Geography. Published by National Geographic Society. Revised, 1997.

Birkvad, B. (1997). Teacher professional development in Denmark. The Phi Delta Kappan, 78(8), 611-614.

Borko, H. (2004). Professional development and teacher learning: Mapping the terrain. Educational Researcher, 33(8), 3-15. http://dx.doi.org/10.3102/0013189X033008003

Bradbeer, J. (1999). Barriers to interdisciplinary: Disciplinary discourses and student learning. Journal of Geography in Higher Education, 23, 381-396. http://dx.doi.org/10.1080/03098269985326

Carano, K., \& Berson, M. (2007). Breaking Stereotypes: Constructing Geographic Literacy and Cultural Awareness through Technology. The Social Studies, 98, 65-69. http://dx.doi.org/10.3200/TSSS.98.2.65-70

Connelly, M., \& Clandinin, D. (1990). Stories of Experience and Narrative Inquiry. Educational Researcher, 19, 2-14. http://dx.doi.org/10.3102/0013189X019005002

Darling-Hammond, L. (1997). Doing what matters most: Investing in quality teaching. New York: National Commission on Teaching and America's future

Darling-Hammond, L. (1999). Professional development for teachers: Setting the stage for learning from teaching. Santa Cruz, CA: The Center for the Future of Teaching and learning.

Darling-Hammond, L. (2012). Creating a comprehensive system for evaluating and supporting effective teaching. Standord, CA. Stanford Center for Opportunity Policy in Education.

Den Brok, P. (2001). Teaching and student outcomes: A study on teachers' thoughts and actions from an interpersonal and a learning activities perspective. Utrecht: W.C.C.

Denzin, N. K., \& Lincoln, Y. S. (1994). Handbook of qualitative research. Thousand Oaks, CA: Sage.

Desimone, L. M. (2009). Improving impact studies of teachers' professional development: Toward better conceptualizations and measures. Educational Researcher, 38(3), 181-199. http://dx.doi.org/10.3102/0013189X08331140

Desimone, L. M. (2011). A primer on effective professional development. The Phi Delta Kappan, 92(6), 68-71. http://dx.doi.org/10.1177/003172171109200616

Desimone, L. M., Garet, M., Birman, B., Porter, A., \& Yoon, K. S. (2002). How do district management and implementation strategies relate to the quality of the professional development that districts provide to teachers? Teachers College Record, 104(7), 1265-1312. http://dx.doi.org/10.1111/1467-9620.00204

Estrada, P. (2005). The courage to grow: A researcher and teacher linking professional development with small-group reading instruction and student achievement. Research in the Teaching of English, 39(4), 320-364.

Freire, P. (2010). Pedagogy of the Oppressed. New York: The Continuum International Publishing Group, Ltd.

Gersmehl, P. (2006). Wanted: A Concise List of Neurologically Defensible and Assessable Spatial Thinking Skills. Journal of Research in Geographic Education, 8, 5-37.

Gersmehl, P. (2008). Teaching Geography, The Guilford Press, copyright Association of American Geographers 
Grant, S. G. (2005). More journey than end: A case study of ambitious teaching: In E. A. Yeager, \& O. L. Davis (Eds.), Wise social studies teaching in an age of high-stakes testing: Essays on classroom practices and possibilities (pp. 117-130). Greenwich, CT: Information Age Publishing.

Hagood, M. (2002). Critical literacy for whom? Reading Research and Instruction, 41, 247-264. http://dx.doi.org/10.1080/19388070209558369

Heck, D. J., Banilower, E. R., Weiss, I. R., \& Rosenberg, S. L. (2008). Studying the effects of professional development: The case of the NSF's local systemic change through teacher enhancement initiative. Journal for Research in Mathematics Education, 39(2), 113-152.

Henry, J. (1989). Meaning and practice in experiential learning. Making Sense of Experiential Learning, 25-37.

Hill, H. C. (2007). Learning in the teaching workforce. The Future of Children, 17(1), 111-127. http://dx.doi.org/10.1353/foc.2007.0004

Hong, H., \& Hamot, G. (2015). The associations of teacher professional characteristics, school environment factors and state testing policy and social studies educators' instructional authority. The Journal of Social Studies Research, 39, 225-241. http://dx.doi.org/10.1016/j.jssr.2015.06.009

Howell, J. B., \& Saye, J. W. (2016). Using lesson study to develop a shared professional teaching knowledge culture among 4th grade social studies teachers. Journal of Social Studies Research, 40, 25-37.

http://dx.doi.org/10.1016/j.jssr.2015.03.001

Kennedy, M. (1989). Form and substance of inservice teacher education. (Research monograph No. 13). Madison: University of Wisconsin-Madison, National Institute for Science Education.

Klooster, P. M., Visser, M., \& de Jong, M. (2008). Comparing two image research instruments: The Q-sort method versus the Likert attitude questionnaire. Food Quality and Preference, 19, 511-518. http://dx.doi.org/10.1016/j.foodqual.2008.02.007

Koppich, J. E., Toch, T., \& Podgursky, M. (2000). The federal role in teacher professional development. Brookings Papers on Education Policy, 3, 265-305. http://dx.doi.org/10.1353/pep.2000.0010

Libbee, M., Mater, M., \& Schaftenaar, L. (2011). Can professional Development Enhance Student Achievement, and Prove it? Results of the 1999-2003 Michigan Achievement Project. "Can professional Development Enhance Student Achievement, and prove it? Results of the 1999-2003 Michigan Achievement Project" in Geographic Literacy in the United States: Challenges and Opportunities in an NCLB Era, Edited by Gary Elbow, David Rutherford, and Christopher Shearer, National Council for Geographic Education, 2011, pg. 38-44.

Little, J. W. (1989). District policy choices and teachers' professional development opportunities. Educational Evaluation and Policy Analysis, 11(2), 165-179. http://dx.doi.org/10.2307/1163783

Little, J. W. (1993). Teachers' professional development in a climate of educational reform. Educational Evaluation and Policy Analysis, 15(2), 129-151. http://dx.doi.org/10.3102/01623737015002129

Meyer, A., Rose, D. H., \& Gordon, D. T. (2013). Universal design for learning theory and practice. Wakefield, MA: National Center on Universal Design for Learning.

National Council for the Social Studies. (2007). Academic freedom and the social studies teacher. Available from http://www.socialstudies.org/position/academicfreedom.

Nelson, L. L. (2014). Design and deliver: Planning and teaching using universal design for learning. Baltimore: Paul H. Brooks Publishing.

Opfer, V. D., \& Pedder, D. (2011). Conceptualizing teacher professional. Review of Educational Research, 81(3), 376-407. Retrieved 07-06-2016, from http://www.jstor.org/stable/23014297

Parker, B., \& Howard, A. (2009). Beyond economics: Using social class life-based literary narratives with pre-service and practicing social studies and English teachers. The High School Journal, 92(3), 3-13. http://dx.doi.org/10.1353/hsj.0.0021

Pullin, D. C., \& Haertel, E. H. (2008). Assessment through the lens of “opportunity to learn”. In. Moss, P. A., Pullin, D. C., Gee, J. P., Haertel, E. H., \& Young, L. J. (Eds.). (2008). Assessment, equity, and opportunity to learn. Cambridge University Press. http://dx.doi.org/10.1017/cbo9780511802157.014

Putnam, R., \& Borko, H. (1997). Teacher learning: Implications of new views of cognition. In B. J. Biddle, T. L. Good, \& I. F. Goodson (Eds.). The international handbook of teachers and teaching (pp. 1223-1296).Dordrecht, The Netherlands: Kluwer. http://dx.doi.org/10.1007/978-94-011-4942-6_30 
Rappolt-Sclichtmann, G., Daley, S., \& Rose, T. (2012). A research reader in Universal Design for Learning. Cambridge, MA: Harvard Educational Press

Salinas, C. (2006). Teaching in a high-stakes testing setting. In S. G. Grant (Ed.) Measuring history: Cases of state-level testing across the United States (pp. 177-193). Greenwich, CT: Information Age Publishing.

Servage, L. (2009). Who is the "professional" in a professional learning community? An exploration of teacher professionalism in collaborative professional development settings. Canadian Journal of Education/Revue Canadienne De l'Éducation, 32(1), 149-171.

Silverman, D. (2000). Doing qualitative research: A practical handbook. London: Sage.

Sinfield, I., \& Hawkins, L. (2006). Critical Literacy: Policy and Practice. Orbit, 36, 27.

Stoltman, J. (1988). Geography and history in the curriculum: Relationships between space and time. Conference paper presented at California Council for Social Studies March 1988. http://files.eric.ed.gov/fulltext/ED316484.pdf. Retrieved on October 22, 2015.

Susan, W. C. (2007). The possibilities of situated learning for teacher preparation: The professional development partnership. Music Educators Journal, 93(3), 44-48. http://dx.doi.org/10.1177/002743210709300319

Thomas-Brown, K. (2011). Teaching for Geographic Literacy: Our Afterschool Geography Club. The Social Studies, 102, 181-189. http://dx.doi.org/10.1080/00377996.2010.509373

Thomas-Brown, K. \& Richards, A. (2015) Critical intersections of knowledge and pedagogy: Why the geographic literacy of preservice elementary teachers matter? Review of International Geographic Education Online, 5(3), 249-273.

Vontz, T. S., Franke, J., Burenheide, B., \& Bietau, L. (2007). Building bridges in social studies education: Professional development school partnerships. The Journal of Educational Research, 100(4), 254-262. http://dx.doi.org/10.3200/JOER.100.4.254-264

Vygotsky, L. (1986). Thought and Language. Cambridge, MIT Press: Massachusetts.

Wayne, A. J., Yoon, K. S., Zhu, P., Cronen, S., \& Garet, M. S. (2008). Experimenting with teacher professional development: Motives and methods. American Educational Research Association, 37(8), 469-479. http://dx.doi.org/10.3102/0013189x08327154

Wiggins, G., \& McTighe, J. (1998). Understanding by Design. Upper Saddle River, N.J.: Merrill Education/ASCD, 1998.

Wilson, S. M., \& Berne, J. (1999). Teacher learning and the acquisition of professional knowledge: An examination of research on contemporary professional development. In A. Iran-Nejad and P. D. Pearson (Eds.), Review of Research in Education 24, 173-209. http://dx.doi.org/10.2307/1167270

Wolk, S. (2003). Teaching for Critical Literacy in Social Studies. The Social Studies, 94(3), 101-106. http://dx.doi.org/10.1080/00377990309600190

\section{$(\mathrm{Cc}) \mathrm{BY}$}

This work is licensed under a Creative Commons Attribution 3.0 License. 